\title{
A case of giant cell hepatitis recurring after liver transplantation and treated with ribavirin
}

\author{
Ziad Hassoun ${ }^{1}$, Bich N'Guyen ${ }^{2}$, Jean Côté ${ }^{2}$, Denis Marleau ${ }^{1}$, Bernard Willems ${ }^{1}$, André Roy ${ }^{3}$, Michel Dagenais $^{3}$, \\ Réal Lapointe $^{3}$, Richard Letourneau ${ }^{3}$, Jean-Pierre Villeneuve ${ }^{1}$
}

\begin{abstract}
Z Hassoun, B N'Guyen, J Côté, et al. A case of giant cell hepatitis recurring after liver transplantation and treated with ribavirin. Can J Gastroenterol 2000;14(8):729-731. A patient who underwent orthotopic liver transplantation for giant cell hepatitis with cirrhosis and in whom giant cell hepatitis recurred twice after orthotopic liver transplantation is reported. He was treated with ribavirin with an excellent result. The literature on this subject is reviewed. This observation clearly confirms the efficacy of ribavirin for the treatment of giant cell hepatitis, thus providing evidence for its viral origin.
\end{abstract}

Key Words: Cirrhosis; Giant cell hepatitis; Liver failure; Orthotopic liver transplantation; Ribavirin

\section{Récurrence d'une hépatite à cellules géantes traitée à la ribavirine après une greffe du foie \\ RÉSUMÉ : On présente ici le cas d'un patient qui a subi une greffe du foie orthotopique pour une hépatite à cellules géantes avec cirrhose et chez qui l'hépatite à cellules géantes est réapparue deux fois après la greffe. Le pa- tient a été traité à la ribavirine avec un excellent résultat. La littérature sur ce sujet est passée en revue. Ce rapport de cas confirme clairement l'effica- cité de la ribavirine pour le traitement de l'hépatite à cellules géantes con- firmant de ce fait son origine virale.}

G iant cell hepatitis $(\mathrm{GCH})$ is a relatively common pathological finding in neonates and infants, and is associated with a variety of conditions, such as intra- and extrahepatic biliary atresia, infectious or metabolic diseases, and the so-called neonatal hepatitis (1). It has occasionally been described in adults, with features suggesting a viral origin and a rapidly progressive course (2). Its recurrence after liver transplantation has been reported (3), as has its treatment with ribavirin after orthotopic liver transplantation (OLT) in one patient (4). We report a patient in whom GCH recurred twice after OLT and was treated with ribavirin.

\section{CASE PRESENTATION}

A 42-year-old patient underwent OLT in June 1990 for $\mathrm{GCH}$ with cirrhosis. Before liver transplantation, he tested negative for hepatitis $B$ surface antigen $\left(\mathrm{HB}_{\mathrm{s}} \mathrm{Ag}\right)$, hepatitis $\mathrm{B}$ surface antibodies, hepatitis B core antibodies, hepatitis C virus antibodies, Epstein Barr virus (EBV) (viral capsid antigen and EBV-determined nuclear antigen) antibodies, antihuman immunodeficiency virus antibodies, antimitochondrial antibodies, antinuclear antibodies and smooth muscle antibodies. He proved later to be hepatitis $\mathrm{C}$ virus RNAnegative as well. He was immune to cytomegalovirus. $\mathrm{GCH}$

This article was a winning case submission from "Consults in Gastroenterology: A Case Study Competition for Fellows and Residents in Gastroenterology"

${ }^{1}$ Liver Unit, ${ }^{2}$ Pathology Department and ${ }^{3}$ Hepatobiliary Surgery Unit, CHUM - Hôpital Saint-Luc and the University of Montreal, Montreal, Quebec

Correspondence and reprints: Ziad Hassoun, Centre de Recherche du CHUM, Hôpital Saint-Luc, 264 René-Lévesque Blvd E, Third Floor, Montréal, Québec H2X 1P1. Telephone 514-281-2444 ext 5706, fax 514-281 2492, e-mail ziad.hassoun@videotron.ca

Received April 7, 2000. Accepted April 10, 2000 


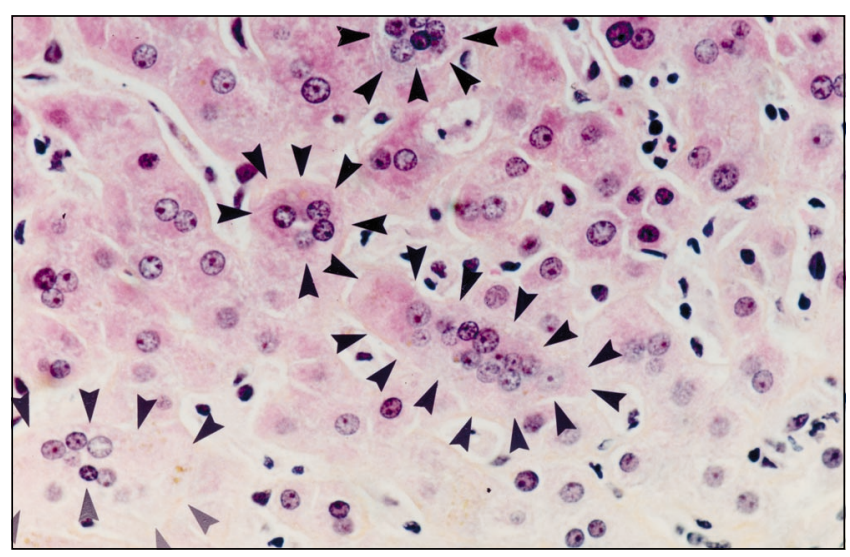

Figure 1) Biopsy specimen showing recurrence of giant cell hepatitis on the second transplanted liver after the withdrawal of ribavirin. Numerous multinucleated giant cells (arrowheads) are visible on this photomicrograph, as are multiple areas of lobular inflammation.

recurred after OLT, and he acquired hepatitis B virus (HBV) at the time of transplantation. In the years that followed, he remained $\mathrm{HB}_{\mathrm{s}} \mathrm{Ag}$-positive, hepatitis e antigen-positive and HBV DNA-positive. Serum transaminase levels were persistently abnormal (around $100 \mathrm{U} / \mathrm{L}$ ). His disease progressed to cirrhosis, with serial liver biopsy specimens showing mixed features of syncytial $\mathrm{GCH}$ and chronic hepatitis $B$ with $\mathrm{HB}_{\mathrm{s}} \mathrm{Ag}$ and hepatitis $\mathrm{B}$ core antigen $\left(\mathrm{HB}_{\mathrm{c}} \mathrm{Ag}\right)$ positivity. $\mathrm{He}$ was started on lamivudine $100 \mathrm{mg}$ daily in March 1996. Eight weeks later, his serum was negative for HBV DNA when tested with the Digene (USA), Abbott (USA) and Chiron (USA) assays, but serum transaminase concentrations remained persistently abnormal, and two liver biopsies performed six and 12 months after starting lamivudine showed no change in the inflammatory activity in the liver nor in the intensity of $\mathrm{Hb}_{\mathrm{c}} \mathrm{Ag}$ staining. His serum was $\mathrm{HBV}$ DNA-positive when measured by polymerase chain reaction (National Genetics Institute, USA) in May 1997. The HBV genome was sequenced, and a YMDD mutation was demonstrated. Famciclovir $500 \mathrm{mg}$ tid was added in August 1997. Liver function continued to deteriorate, and the patient received a second liver transplant in May 1998. He initially received hepatitis B immune globulin, famciclovir and lamivudine prophylaxis; famciclovir was subsequently withdrawn. Liver function test (LFT) results remained abnormal, while $\mathrm{HB}_{\mathrm{s}} \mathrm{Ag}$ and HBV DNA test results were negative. A liver biopsy performed in July 1998 showed portal and periportal infiltration, with mononuclear elements, bridging necrosis, mild intralobular degeneration and focal necrosis. Within the lobule, numerous multinucleated hepatocytes were noted; there was moderate fibrosis. The patient was negative for $\mathrm{HB}_{\mathrm{s}} \mathrm{Ag}$ and $\mathrm{HB}_{\mathrm{c}} \mathrm{Ag}$ on immunohistochemistry, and for cytomegalovirus, EBV and herpes simplex virus. Lamivudine and hepatitis B immune globulin were continued, and ribavirin (400 mg bid) was added in August 1998. LFT results improved gradually and normalized completely in February 1999; ribavirin was then stopped. In April 1999, LFT results deteriorated, with an increase in serum bilirubin up to $400 \mu \mathrm{mol} / \mathrm{L}$. A liver biopsy showed recurrence of severe

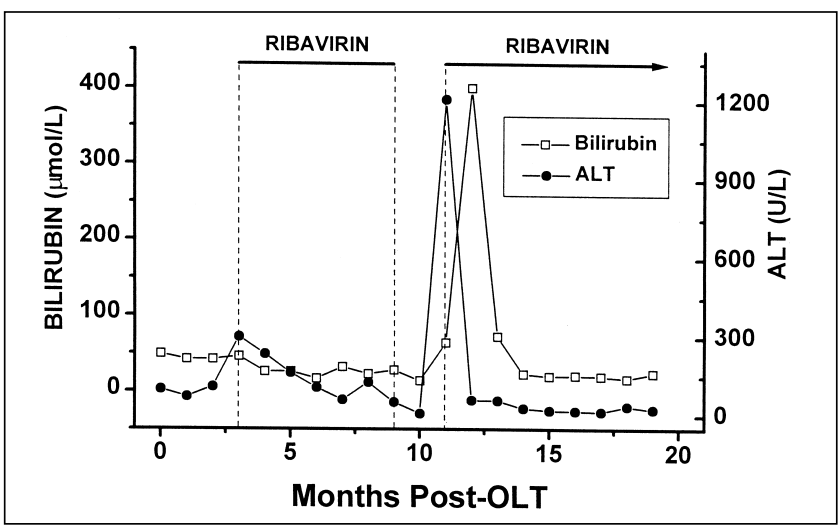

Figure 2) Biochemical profile of the patient after the second liver transplantation, showing the evolution of serum alanine aminotransferase (ALT) and bilirubin with respect to ribavirin treatment. Time 0 is the time of the second orthotopic liver transplantation (OLT)

GCH (Figure 1), and ribavirin was reintroduced with a drastic improvement in LFT results, which normalized completely in August 1999 and have remained normal with continued ribavirin treatment (Figure 2). A control liver biopsy performed in May 1999 demonstrated a marked decrease in portal and lobular inflammation, and in the number of giant cells.

\section{DISCUSSION}

$\mathrm{GCH}$ is characterized by the presence throughout the liver of numerous enlarged multinucleated hepatocytes with abundant cytoplasm (1). It is a nonspecific reaction in neonates and infants with various liver diseases. The term 'postinfantile GCH' was coined by Thaler (5) to describe this histological finding in the older patient. In 1991, Phillips et al (2) described 10 patients who had syncytial GCH, with a severe course and a poor outcome. Structures resembling the nucleocapsids of paramyxoviruses were seen on electron microscopy, but the putative virus could not be identified. In 1993, Roberts et al (6) reported an infant with severe neonatal GCH who was treated effectively with a 10-day course of intravenous ribavirin. In 1994, Pappo et al (3) described five patients who had GCH that recurred after liver transplantation. In 1997, Durand et al (4) reported an adult patient with subfulminant GCH leading to OLT and recurring in the transplanted liver. This patient was treated with two 21-day courses of intravenous ribavirin; LFT results and liver histology normalized. In 1998, Fimmel et al (7) performed elaborate molecular biology manipulations on the liver tissue of a patient affected by $\mathrm{GCH}$ and obtained a positive signal on in situ hybridization studies with a probe directed against the measles fusion protein. Taken together, these observations suggest that a yet unidentified virus, related to Paramyxoviridae, may play a role in the pathogenesis of $\mathrm{GCH}$.

Some authors have suggested, however, that other etiological factors may be implicated in $\mathrm{GCH}$, based on retrospective case reviews and case reports (8-14). The patients described had a variety of associated conditions, including autoimmune features, with or without overt autoimmune 
disease, and hypereosinophilia. In some patients, there was an identifiable cause of liver disease - autoimmune hepatitis, acute hepatitis $\mathrm{A}$ or $\mathrm{B}$, chronic hepatitis $\mathrm{C}$ or drug exposure. In others, the etiological work-up remained negative. Patients with or without autoimmune features have been treated with immunosuppressive therapy $(8,10-12,14)$, with favourable results in most cases. Even in untreated patients, the outcome appeared to be much less ominous than that described by Phillips et al (2).

Our patient had the typical histopathological features of $\mathrm{GCH}$, and no cause was found before the first transplantation and after the second one. GCH recurred on the two transplanted livers despite immunosuppression with a tripledrug regimen (prednisone, azathioprine and cyclosporine) and was effectively treated with oral ribavirin. On withdrawal of this antiviral drug, severe recurrence of GCH that responded to the reinitiation of therapy was documented. It might be implied from this observation that $\mathrm{GCH}$ was, in

\section{REFERENCES}

1. Desmet VJ, Callea F. Cholestatic syndromes of infancy and childhood. In: Zakim D, Boyer TD, eds. Hepatology: A Textbook of Liver Disease, 3rd edn. Philadelphia: WB Saunders, 1996:1649-98.

2. Phillips MJ, Blendis LM, Poucell S, et al. Syncytial giant-cell hepatitis: sporadic hepatitis with distinctive pathological features, a severe clinical course, and paramyxoviral features. N Engl J Med 1991;324:455-60.

3. Pappo O, Yunis E, Jordan JA, et al. Recurrent and de novo giant cell hepatitis after orthotopic liver transplantation. Am J Surg Pathol 1994;18:804-13.

4. Durand F, Degott C, Sauvanet A, et al. Subfulminant syncytial giant cell hepatitis: recurrence after liver transplantation treated with ribavirin. J Hepatol 1997;26:722-6.

5. Thaler H. Post-infantile giant cell hepatitis. Liver 1982;2:393-403.

6. Roberts E, Ford-Jones EL, Phillips MJ. Ribavirin for syncytial giant cell hepatitis. Lancet 1993;341:640-1. (Lett)

7. Fimmel CJ, Guo L, Compans RW, et al. A case of syncytial giant cell hepatitis with features of a paramyxoviral infection. Am J Gastroenterol 1998;93:1931-7.

8. Devaney K, Goodman ZD, Ishak KG. Postinfantile giant-cell transformation in hepatitis. Hepatology 1992;16:327-33. this case, related to a transmissible factor that responded to ribavirin and was thus likely to be viral. It is noteworthy that continuous treatment seemed necessary, while short courses of intravenous ribavirin appeared to be sufficient in the two previously published cases $(4,6)$.

\section{CONCLUSIONS}

$\mathrm{GCH}$ seems to encompass a wide spectrum of liver diseases in adults, as it does in children. A cause may be evident in some cases and absent in others. Autoimmunity and infection with an as yet unidentified virus have been implicated most frequently. Clinical courses are highly variable. In some cases, GCH seems to respond to immunosuppressive therapy and in others to antiviral therapy; sometimes it responds to none of these therapies (15). We present a case that demonstrates clearly the efficacy of ribavirin treatment for $\mathrm{GCH}$ and thus adds evidence for its viral origin in some cases.

9. Lau JYN, Koukoulis G, Mieli-Vergani G, Portmann BC, Williams R. Syncitial giant-cell hepatitis - a specific disease entity? J Hepatol 1992;15:216-9.

10. Johnson SJ, Mathew J, MacSween RNM, Bennet MK, Burt AD. Postinfantile giant cell hepatitis: histological and immunochemical study. J Clin Pathol 1994:47:1022-7.

11. Protzer U, Dienes HP, Bianchi L, et al. Post-infantile giant cell hepatitis in patients with primary sclerosing cholangitis and autoimmune hepatitis. Liver 1996;16:274-82.

12. Tordjmann T, Grimbert S, Genestie C, et al. Hépatite à cellules multinucléées de l'adulte. Étude chez 17 malades. Gastroenterol Clin Biol 1998;22:305-10.

13. Kumar A, Minuk GY. Postinfantile giant cell hepatitis in association with hypereosinophilia. Gastroenterology 1991;101:1417-9.

14. Rabinovitz M, Demetris AJ. Postinfantile giant cell hepatitis associated with anti-M2 mitochondrial antibodies. Gastroenterology 1994;107:1162-4.

15. Horsmans Y, Galant C, Nicholas ML, Lamy M, Geubel AP. Failure of ribavirin or immunosuppressive therapy to alter the course of post-infantile giant-cell hepatitis. J Hepatol 1995;22:382. (Lett) 


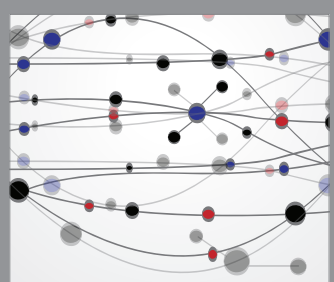

The Scientific World Journal
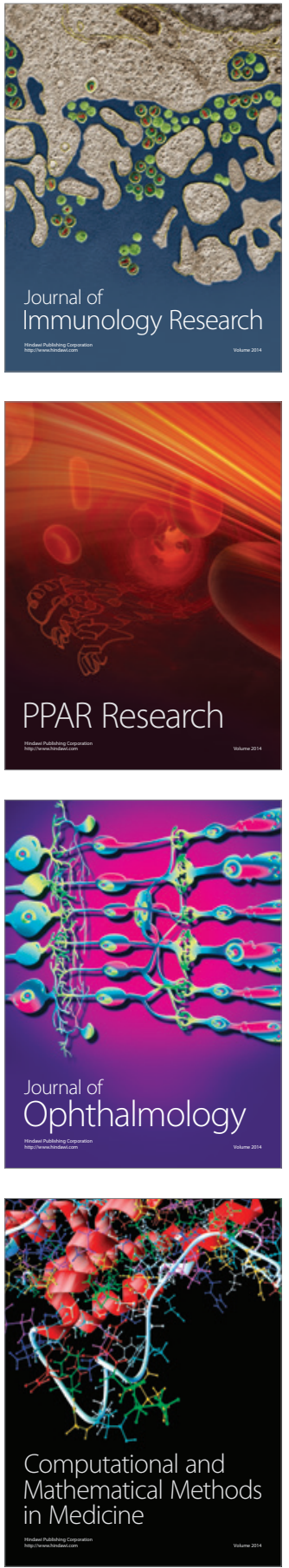

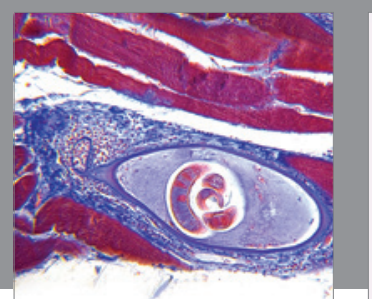

Gastroenterology Research and Practice

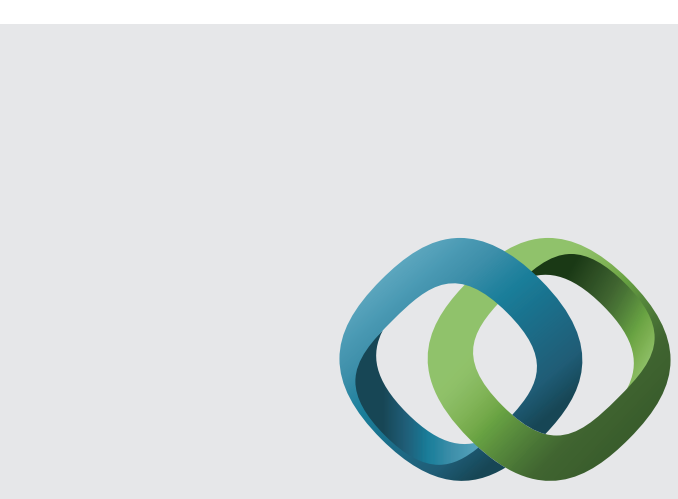

\section{Hindawi}

Submit your manuscripts at

http://www.hindawi.com
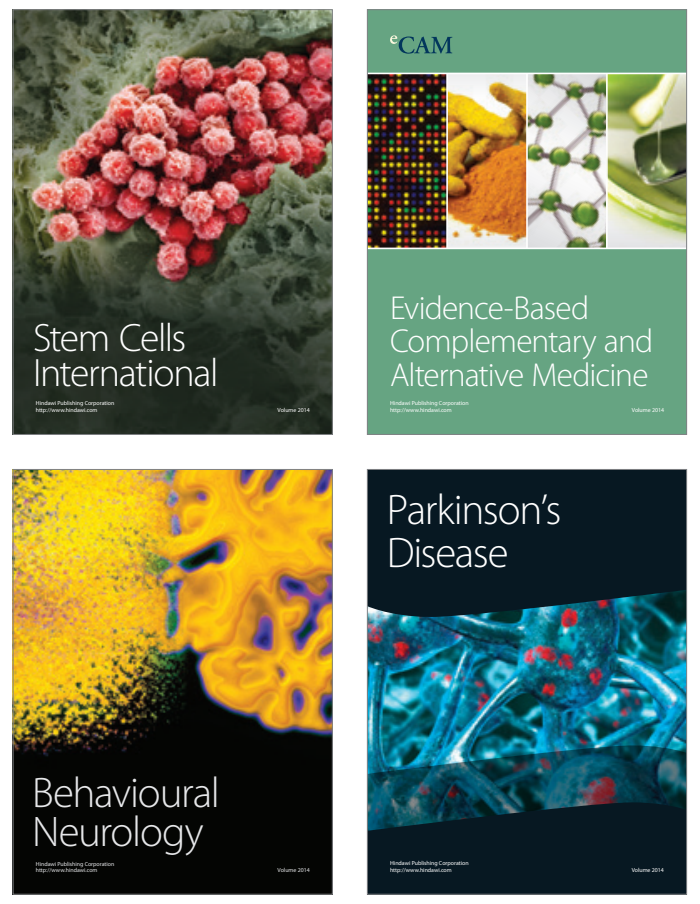
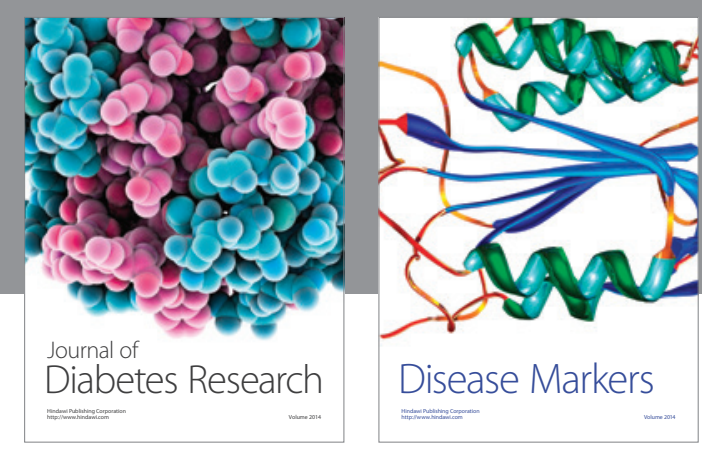

Disease Markers
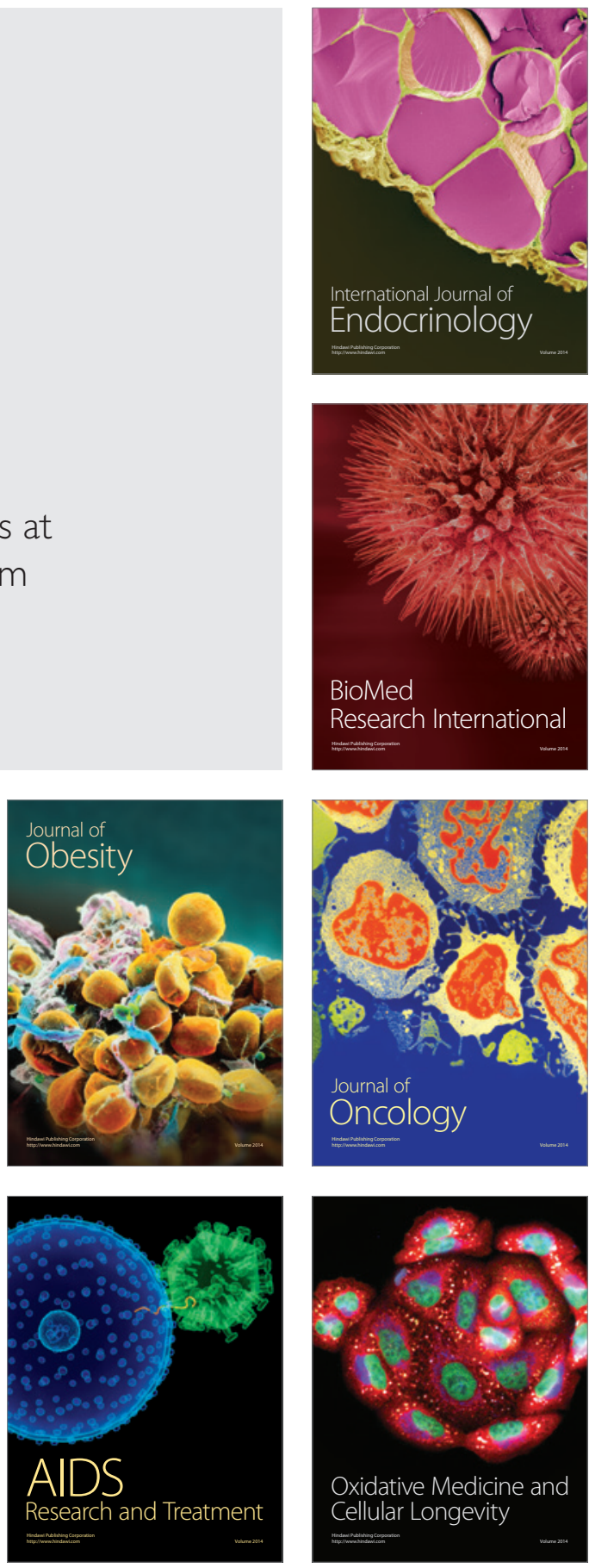